ERRATUM

Ofelia Alvarez • Gaston Zilleruelo • Dale Wright •

Brenda Montane • Gabriela Lopez-Mitnik

\title{
Serum cystatin C levels in children with sickle cell disease
}

Published online: 5 July 2006

(C) IPNA 2006

\section{Pediatr Nephrol (2006) 21: 533-537}

In the introduction, the expanded form of CSSCD should read Cooperative Study of Sickle Cell Disease (CSSCD) and not Comprehensive Study of Sickle Cell Disease.

The authors apologize for this error.

The online version of the original article can be found at: http://dx. doi.org/10.1007/s00467-006-0033-6

O. Alvarez $(\bowtie) \cdot D$. Wright

Division of Pediatric Hematology, University of Miami,

1611 NW 12th Avenue, ACC West, Rm 514,

Miami, FL 33136, USA

e-mail: oalvarez2@med.miami.edu

Tel.: +1-305-5855635

Fax: +1-305-3258387

G. Zilleruelo $\cdot$ B. Montane

Division of Pediatric Nephrology, University of Miami,

Miami, FL, USA

G. Lopez-Mitnik

Department of Pediatrics, University of Miami,

Miami, FL, USA 